\title{
Tretthet etter kreftbehandling
}

Tretthet er det hyppigste symptomet under kreftbehandling. Nesten alle vil oppleve akutt tretthet under behandlingen og rett etterpå (1). Det er ofte behandlingen og ikke kreftsykdommen som gir tretthetsfølelsen. Inflammasjon er for tiden i søkelyset som bindeledd mellom kreftbehandlingen og akutt tretthet. I tillegg kan en rekke andre biologiske forhold ha betydning (2). I mange studier har psykisk ubehag (psychological distress) vært forbundet med tretthet (3). De fleste vil oppleve at symptomet gradvis forsvinner i takt med at den fysiske og psykiske helsen bedres etter avsluttet behandling.

Dessverre vil ikke alle oppleve denne bedringen. Hos inntil $30 \%$ vil trettheten bli kronisk (1). Forekomsten av slik kronisk tretthet varierer mellom kreftdiagnosene. De affiserte vil oppleve at de mangler energi, at hukommelse og konsentrasjonsevne er svekket, at søvnen er forstyrret (ofte forlenget) og at symptomet blir verre under stress. Kronisk tretthet etter avsluttet behandling er forbundet med en rekke biologiske og psykologiske faktorer. Seneffekter kan ha betydning, f.eks. nedsatt lungefunksjon (4). Psykisk ubehag i form av uro, bekymring, pessimisme og lett nedsatt stemningsleie er den faktoren som gjennomgående er vist å ha sammenheng med symptomet (3).

Vi vet ofte ikke hvorfor den enkelte opplever kronisk tretthet. Blant trette pasienter som har fått samme behandling for samme kreftdiagnose, vil årsakene variere. I nyere forskning har man i større grad undersøkt faktorer som vedlikeholder symptomet. Både fysisk inaktivitet og påtrengende minner og tanker om kreftbehandlingen (intrusjon) er av betydning $(5,6)$. Dette peker mot en modell som er velkjent ved en annen kronisk subjektiv helseplage - kronisk smerte. I tråd med dette er kognitiv atferdsterapi og gradert kondisjonstrening gode behandlingsalternativer $(7,8)$. Medikamentell behandling har ingen plass, med unntak av behandling av underliggende tilstander som hormonmangel eller depresjon (9). Akupunktur og yoga kan ha positiv effekt $(10,11)$.

Som Brekke beskriver er symptomet byrdefullt. Tretthet har betydelig større negative funksjonelle konsekvenser enn andre vanlige symptomer hos kreftpasienter (12). Likevel har ikke det fått samme plass innenfor onkologisk symptomrettet behandling som smerte eller kvalme. Den biomedisinske sykdomsmodellen er oftest utilstrekkelig både klinisk og $\mathrm{i}$ forskning, og funnene fra de empiriske studiene viser at en biopsykososial forståelse er nødvendig.

Noen enkle tiltak kan ofte være til hjelp, og de fleste leger kan gi råd om slike. Det finnes generell informasjon både på Kreftforeningens hjemmeside og i bøker (13). Informasjon om akutt tretthet før og under kreftbehandling bør formidle at de fleste vil bli bra. Hvis trettheten blir kronisk, vil det ofte være forhold $\mathrm{i}$ håndteringen av symptomet som pasienten kan korrigere selv. Det kan være dysfunksjonell atferd som overforbruk av krefter i gode perioder (med påfølgende tretthet) og opplevde krav om ytelse som overstiger pasientens energinivå eller søvnforstyrrelse(r). Prinsippene for kondisjonstrening er kjent av de fleste leger. For noen pasienter kan en personlig trener med relevant erfaring være nyttig. Katastrofetenkning, bitterhet og vedvarende grubling (ruminering) omkring symptomet og dets negative konsekvenser er grunnlag for å diskutere kognitiv terapi. Heldigvis blir mange bedre etter hvert, og bedringen er gjerne forbundet med at pasienten opplever å ha mer kontroll over symptomet.

NAVs håndtering av søknader om trygdeytelser for kronisk tretthet etter kreftbehandling varierer. De gode løsningene vil innebære samarbeid og fleksible løsninger. Urimelige krav om ytelse kan låse de involverte i et negativt samspill som motvirker persontilpassede løsninger.

Bruken av det engelske ordet «fatigue» om denne seneffekten er blitt vanlig blant helsepersonell. Dette bidrar til mystifisering. Jeg foreslår at vi endrer praksis og bruker norsk (14).

Jon Håvard Loge

j.h.loge@medisin.uio.no

Jon Håvard Loge (f. 1953) er leder for Nasjonal kompetansetjeneste for seneffekter etter kreftbehandling, Oslo universitetssykehus, og professor II ved Avdeling for medisinsk atferdsvitenskap, Universitetet i Oslo.

Ingen oppgitte interessekonflikter
Litteratur

1. Bower JE. Treating cancer-related fatigue: the search for interventions that target those most in need. J Clin Oncol 2012; 30: 4449-50.

2. Stone PC, Minton O. Cancer-related fatigue. Eur J Cancer 2008; 44: 1097-104.

3. Brown LF, Kroenke K. Cancer-related fatigue and its associations with depression and anxiety: a systematic review. Psychosomatics 2009; 50: 440-7.

4. Knobel H, Håvard Loge J, Lund MB et al. Late medical complications and fatigue in Hodgkin's disease survivors. J Clin Oncol 2001; 19: 3226-33.

5. Dupont A, Bower JE, Stanton AL et al. Cancerrelated intrusive thoughts predict behavioral symptoms following breast cancer treatment. Health Psychol 2014; 33: 155-63.

6. Puetz TW, Herring MP. Differential effects of exercise on cancer-related fatigue during and following treatment: a meta-analysis. Am J Prev Med 2012; 43: e1-24.

7. Gielissen MF, Verhagen S, Witjes F et al. Effects of cognitive behavior therapy in severely fatigued disease-free cancer patients compared with patients waiting for cognitive behavior therapy: a randomized controlled trial. J Clin Oncol 2006; 24: $4882-7$

8. Speck RM, Courneya KS, Mâsse LC et al. An update of controlled physical activity trials in cancer survivors: a systematic review and metaanalysis. J Cancer Surviv 2010; 4: 87-100.

9. Minton O, Richardson A, Sharpe M et al. Drug therapy for the management of cancer-related fatigue. Cochrane Database Syst Rev 2010; nr. 7 : CD006704

10. Molassiotis A, Bardy J, Finnegan-John J et al. Acupuncture for cancer-related fatigue in patients with breast cancer: a pragmatic randomized controlled trial. J Clin Oncol 2012; 30: 4470-6.

11. Sadja J, Mills PJ. Effects of yoga interventions on fatigue in cancer patients and survivors: a systematic review of randomized controlled trials. Explore (NY) 2013; 9: 232-43.

12. Stone P, Richardson A, Ream E et al. Cancer-related fatigue: inevitable, unimportant and untreatable? Results of a multi-centre patient survey. Cancer Fatigue Forum. Ann Oncol 2000; 11: 971-5

13. Loge JH, Dahl AA, Fosså SD et al. Kreftoverlevere. Oslo: Gyldendal, 2013.

14. Loge JH, Hem E. Kronisk tretthet. Tidsskr Nor Lægeforen 2002; 122: 1352.

Mottatt 7.4. 2014 og godkjent 8.4. 2014. Redaktør: Erlend Hem. 